\title{
Markers of oxidative/nitrosative stress and inflammation in lung tissue of rats exposed to different intravenous iron compounds
}

This article was published in the following Dove Press journal:

Drug Design, Development and Therapy

I August 2017

Number of times this article has been viewed

\author{
Jorge E Toblli' \\ Gabriel Cao' \\ Jorge F Giani² \\ Fernando P Dominici ${ }^{2}$ \\ Margarita Angerosa'
}

'Laboratory of Experimental Medicine, Hospital Alemán, School of Medicine, University of Buenos Aires, Buenos Aires, Argentina; ${ }^{2}$ Department of Biochemistry, School of Pharmacy, Institute of Chemistry and BiophysicsBiochemistry (UBA-CONICET), Buenos Aires, Argentina
Correspondence: Jorge E Toblli Laboratory of Experimental Medicine, Hospital Alemán, School of Medicine, University of Buenos Aires, Av Pueyrredon, 1640, II I8 Buenos Aires, Argentina

Tel +54 II 48277000 ext 2785

$\mathrm{Fax}+54$ । I 48056087

Email jorgetoblli@fibertel.com.ar
Abstract: Iron deficiency anemia is a frequent complication in clinical conditions such as chronic kidney disease, chronic heart failure, inflammatory bowel disease, cancer, and excessive blood loss. Given the ability of iron to catalyze redox reactions, iron therapy can be associated with oxidative stress. The lung is uniquely susceptible to oxidative stress, and little is known about the effects of intravenous iron treatment in this organ. This study characterized changes in markers of oxidative/nitrosative stress and inflammation in the lung of non-iron deficient, nonanemic rats treated with five weekly doses ( $40 \mathrm{mg}$ iron per $\mathrm{kg}$ body weight) of low molecular weight iron dextran (LMWID), iron sucrose (IS), ferric carboxymaltose (FCM), ferumoxytol (FMX), iron isomaltoside 1000 (IIM), or saline (control). Rats treated with LMWID, FMX, or IIM showed significant changes in most measures of oxidative/nitrosative stress, inflammation, and iron deposition compared to the saline-treated controls, with greatest changes in the LMWID treatment group. Increases in products of lipid peroxidation (thiobarbituric acid reactive substances) and protein nitrosation (nitrotyrosine) were consistent with increases in the activity of antioxidant enzymes (catalase, Cu,Zn-SOD, GPx), decreases in antioxidative capacity (reduced:oxidized GSH ratio), increased levels of transcription factors involved in the inflammatory pathway (NF- $\kappa B, H I F-1 \alpha$ ), inflammatory cytokines (TNF- $\alpha$, IL-6), adhesion molecules (VCAM-1), markers of macrophage infiltration (ED-1), and iron deposition (Prussian blue, ferritin). Since changes in measured parameters in FCM- or IS-treated rats were generally modest, the results suggest that FCM and IS have a low propensity to induce lung inflammation. The relevance of these findings to clinical safety profiles of the tested intravenous iron products requires further investigation.

Keywords: intravenous iron, oxidative stress, nitrosative stress, inflammation, lung, rodent model

\section{Introduction}

Intravenous (iv) iron is utilized for the correction of iron deficiency (ID) and iron deficiency anemia (IDA). ID and IDA are common comorbidities of chronic conditions, including chronic kidney disease, ${ }^{1}$ chronic heart failure, ${ }^{2}$ inflammatory bowel disease ${ }^{3}$ and cancer, ${ }^{4}$ but also associated with perinatal blood loss, ${ }^{5}$ peri-surgical blood loss, ${ }^{6}$ and abnormal uterine bleeding. ${ }^{7}$ Direct uptake of iv iron by the reticuloendothelial system (RES) allows for rapid supply of iron to the bone marrow, even during treatment with erythropoiesis-stimulating agents. ${ }^{4,8,9}$

Marketed iv iron products are formulations of low molecular weight iron dextran (LMWID), sodium ferric gluconate (FG), iron sucrose (IS), ferric carboxymaltose (FCM), and iron isomaltoside 1000 (IIM). One further product, ferumoxytol (FMX), 
was withdrawn from the European market upon request of the marketing authorization holder. ${ }^{10}$ These products are colloidal solutions of complex polynuclear iron(III)-oxyhydroxide nanoparticles stabilized with a carbohydrate ligand, and differences in their composition and physicochemical properties may influence pharmacokinetics and side effect profiles. ${ }^{11-13}$ Iron carbohydrate complexes with lower stability, such as IS and FG, largely dissociate in the plasma. Consequently, a proportion of iron can be released into plasma before uptake by the RES. ${ }^{14}$ This prematurely released "labile" iron can directly bind to transferrin and other proteins (referred to as non-transferrin bound iron, NTBI), leading to unspecific iron uptake by different tissues and organ toxicity. ${ }^{15,16}$

In a non-clinical model of iron-infused healthy, nonanemic rats, different iv iron compounds demonstrated significantly different effects in liver, heart, and kidney. ${ }^{17-19}$ Notably, even products that are marketed as generics of the reference product (IS) exerted different effects on oxidative stress and inflammation. ${ }^{20}$ In a similar non-clinical model, a recent evaluation of selected iv iron compounds suggested that the induction of nitrosative stress markers is highest in the lung as compared to liver, heart, and kidney. ${ }^{21}$

As the lung appears to be particularly susceptible to oxidative stress and injury, it is critical to accurately evaluate the potential of iv iron compounds for lung toxicity. In this study, by analyzing markers of oxidative/nitrosative stress and iron deposition, we compared the toxicological effects of currently available iv iron formulations in lung tissue of healthy rats.

\section{Materials and methods}

\section{Animals and treatments}

All animal experiments were approved by the Hospital Alemán Ethics Committee and the Teaching and Research Committee. Experiments were conducted in strict accordance with the Guide for the Care and Use of Laboratory Animals of the National Institutes of Health. Sprague-Dawley rats ( $n=8$ per group; four male, four female) were fed, housed, and treated (five weekly iv injections of $40 \mathrm{mg}$ iron/ $\mathrm{kg}$ body weight or an equivalent volume of isotonic saline solution) as described previously. ${ }^{22}$ As this study was designed to assess toxicological differences between various parenteral iron therapies, a high iron dose of $40 \mathrm{mg} / \mathrm{kg}$ was chosen to detect clear differences between iron compounds. The administered iv iron products comprised IS (Venofer ${ }^{\circledR}$, American Regent, Shirley, NY, USA), FCM (Ferinject ${ }^{\circledR}$, Vifor (International) Ltd., St Gallen, Switzerland), FMX (Feraheme ${ }^{\circledR}$, AMAG Pharmaceuticals Inc., Lexington, MA, USA), LMWID (Infed $^{\circledR}$, Watson Pharma Inc., Morristown, NJ, USA), IIM
(Monofer $^{\circledR}$, Pharmacosmos A/S, Holbæk, Denmark), or saline. Twenty-four hours after the final iv iron injection, rats were sacrificed and organs perfused with ice-cold saline before removal. Tissue samples for assessment of oxidative/nitrosative stress parameters were immersed in liquid nitrogen and stored at $-80^{\circ} \mathrm{C}$ until analysis. Tissue samples for histological evaluation were submerged in fixation solution (phosphate-buffered 10\% formaldehyde, $\mathrm{pH} 7.2$ ), embedded in paraffin, and stored at room temperature.

Investigators were blinded to the treatments.

\section{Oxidative stress evaluation}

Portions of lung samples were homogenized in ice-cold $250 \mathrm{mM}$ sucrose solution (1:3, w:v) for the determination of GSH, Cu,Zn-SOD, and GPx. For the determination of malondialdehyde (MDA), lung samples were homogenized in $50 \mathrm{mM}$ sodium phosphate buffer ( $\mathrm{pH} 7.4 ; 1: 10$, w:v). MDA was determined as thiobarbituric acid reactive species, and catalase as described previously. ${ }^{17,18}$

\section{Nitrosative stress evaluation}

Lung samples were homogenized in solubilization buffer $(1: 10 \mathrm{w} / \mathrm{v})$, and clarified lysates were analyzed for nitrotyrosine via Western blotting with an anti-nitrotyrosine antibody (AB5411; EMD Millipore, Billerica, MA, USA) as previously described. ${ }^{19,23,24}$ Immunoblots were developed by enhanced chemiluminescence (Amersham, Pittsburgh, PA, USA). Autoradiographs were scanned and band intensities quantified by digital densitometry using Gel-Pro Analyzer 4.0 software (Media Cybernetics, Rockville, MD, USA).

Protein loading was assessed by stripping the blot and re-probing with anti- $\beta$-actin (A2066; Sigma-Aldrich Co., St Louis, MO, USA).

\section{Immunohistochemistry, cytochemistry, histomorphometry, and light microscopy}

Preparation and processing of tissue samples for evaluation by light microscopy was performed as described previously. ${ }^{17,18}$ In brief, portions of lung were cut, fixed in phosphatebuffered 10\% formaldehyde ( $\mathrm{pH} 7.2$ ), and embedded in paraffin. Then, $3 \mu \mathrm{m}$ sections were prepared and processed. Ferritin was detected with goat anti-ferritin heavy chain $(\mathrm{H})$ polyclonal antibody (sc-14416; Santa Cruz Biotechnology Inc., Dallas, TX, USA) and mouse anti-ferritin light chain (L) monoclonal antibody (sc-14420; Santa Cruz Biotechnology Inc.). Cytokines were detected with monoclonal antibodies against rat TNF- $\alpha$ (AF-510-NA; R\&D Systems, Inc., Minneapolis, MN, USA) and IL-6 (sc-1265; Santa Cruz Biotechnology Inc.). VCAM-1, HIF-1 $\alpha$, and VEGF were 
detected with rabbit polyclonal anti-VCAM-1 (sc-8304; Santa Cruz Biotechnology Inc.), mouse monoclonal antiHIF-1 $\alpha$ (Novus Biologicals, Inc., Littleton, CO, USA), and mouse monoclonal anti-VEGF (sc-7269; Santa Cruz Biotechnology Inc.) antibodies, respectively. NF- $\kappa B_{65}$ was detected with mouse monoclonal anti-NF- $\mathrm{\kappa B}_{\mathrm{p} 65}$ (sc-8008; Santa Cruz Biotechnology Inc.) antibody. Nitrotyrosine was detected with a rabbit polyclonal anti-nitrotyrosine antibody (AB5411; EMD Millipore). Macrophages were identified using a mouse anti-rat CD68 (ED1 clone) monoclonal antibody (MCA341; AbD Serotec, Raleigh, NC, USA).

Iron(III) deposits were detected with Prussian blue staining.

For histomorphometry, tissue sections were viewed by light microscopy and images were captured using a digital camera. Images were then processed by an image analyzer (Image-Pro Plus 4.5 for Windows; Media Cybernetics, Silver Spring, MD, USA). Morphological analyses were performed at a magnification of $\times 200$ or $\times 400$. Mean values of positive staining for iron(III), ferritin, TNF- $\alpha$, IL-6, nitrotyrosine, VEGF, and VCAM-1 (expressed as the percentage of area with positive immunostaining $/ \mathrm{mm}^{2}$ ) and nuclear HIF-1 $\alpha$, $\mathrm{NF}-\kappa_{6}{ }_{65}$, and ED1 macrophages (expressed as number of cells with positive staining $/ \mathrm{mm}^{2}$ ) were calculated for samples from each rat. All evaluations were performed by two independent observers. Both observers were blinded to sample identity.

\section{Statistical analysis}

Values are expressed as mean \pm SD. Statistical analyses were performed with absolute values and processed using
GraphPad Prism, version 5.01 for Windows (GraphPad Software, Inc., La Jolla, CA, USA). For parameters with Gaussian distribution, comparisons among groups were performed using ANOVA followed by Tukey's post hoc test. For parameters with non-Gaussian distribution (ie, histology data) comparisons were performed by Kruskal-Wallis test (non-parametric ANOVA) and Dunn's multiple comparison test. A value of $P<0.05$ was considered significant.

\section{Results \\ Oxidative and nitrosative stress}

Levels of MDA, a marker of lipid peroxidation, were significantly elevated in lung homogenates of iv iron-treated compared to saline-treated rats $(P<0.05)$ (Table 1). Rats treated with LMWID or IIM showed the greatest increase in MDA levels. FCM-treated rats had MDA levels closest to those observed in the control group. Compared to the control group, activity levels of the antioxidant enzymes catalase, $\mathrm{CuZn-SOD}$, and GPx were significantly increased in rats treated with LMWID, IIM, and FMX $(P<0.05)$. The ratio of reduced to oxidized GSH (GSH:GSSG ratio), a measure for antioxidative capacity, was significantly decreased in lung samples from animals treated with LMWID, IIM, FMX, and IS compared to levels in controls $(P<0.05)$.

Immunostaining of nitrotyrosine, a marker of nitrosative stress, was significantly increased in lungs of rats treated with LMWID, FMX, and IIM compared to controls $(P<0.05)$. Moreover, nitrotyrosine formation was significantly greater in the LMWID and FMX groups than the FCM and IS groups $(P<0.05)$. Nitrotyrosine formation was primarily localized to alveolar cells (Figure 1). Western blot analysis of solubilized

Table I Oxidative and nitrosative stress parameters

\begin{tabular}{|c|c|c|c|c|c|c|}
\hline Parameter & $\begin{array}{l}\text { IIM } \\
(n=8)\end{array}$ & $\begin{array}{l}\text { IS } \\
(n=8)\end{array}$ & $\begin{array}{l}\text { FCM } \\
(n=8)\end{array}$ & $\begin{array}{l}F M X \\
(n=8)\end{array}$ & $\begin{array}{l}\text { LMWID } \\
(n=8)\end{array}$ & $\begin{array}{l}\text { Control } \\
(n=8)\end{array}$ \\
\hline $\begin{array}{l}\text { TBARs } \\
\text { (nmol MDA/mg protein) }\end{array}$ & $41.3 \pm 2.6^{b}$ & $34.8 \pm 2.4$ & $30.9 \pm 2.2$ & $36.5 \pm 2.2^{c}$ & $45.2 \pm 4.1^{b}$ & $28.1 \pm 2.0^{\mathrm{a}}$ \\
\hline $\begin{array}{l}\text { Catalase } \\
\text { (U/mg protein) }\end{array}$ & $21.3 \pm 1.9$ & $17.0 \pm 1.8^{d}$ & $15.5 \pm 1.7^{d}$ & $20.8 \pm 2.1$ & $24.0 \pm 2.4^{\mathrm{e}}$ & $14.4 \pm 1.5^{d}$ \\
\hline $\begin{array}{l}\text { CuZn-SOD } \\
\text { (U/mg protein) }\end{array}$ & $9.0 \pm 1.0$ & $8.8 \pm 1.1^{d}$ & $7.5 \pm 0.9^{d}$ & $9.1 \pm 1.0$ & $11.6 \pm 0.9^{\mathrm{e}}$ & $7.2 \pm 0.7^{d}$ \\
\hline $\begin{array}{l}\text { GPx } \\
\text { (U/mg protein) }\end{array}$ & $195.6 \pm 15.8$ & $169.2 \pm 16.1^{d}$ & $152.9 \pm 10.3^{d}$ & $184.9 \pm 14.9$ & $224.8 \pm 18.3^{e}$ & $148.8 \pm 13.4^{d}$ \\
\hline $\begin{array}{l}\text { GSH:GSSG } \\
\text { Ratio }\end{array}$ & $7.3 \pm 0.6$ & $7.9 \pm 1.2$ & $9.9 \pm 1 . I^{f}$ & $7.8 \pm 0.9$ & $6.3 \pm 1.2$ & $10.1 \pm 0.9^{f}$ \\
\hline $\begin{array}{l}\text { Nitrotyrosine } \\
\text { (\%/area) }\end{array}$ & $3.4 \pm 0.5$ & $2.8 \pm 0.5$ & $2.8 \pm 0.3$ & $5.6 \pm 0.9^{g}$ & $5.8 \pm 0.9^{g}$ & $2.1 \pm 0.5^{\mathrm{d}}$ \\
\hline
\end{tabular}

Notes: Data presented as mean \pm SD. a $P<0.05$ versus all groups, ${ }^{b} P<0.05$ versus $I S, F C M, F M X,{ }^{c} P<0.05$ versus $F C M,{ }^{d} P<0.05$ versus $L M W I D, F M X$, IIM, ${ }^{e} P<0.05$ versus $F M X$, ${ }^{f} P<0.05$ versus IS, LMWID, FMX, IIM, ${ }^{8 P}<0.05$ versus IS, FCM. IIM, iron isomaltoside 1000 (Monofer ${ }^{\circledR}$, Pharmacosmos A/S, Holbæk, Denmark); IS, iron sucrose (Venofer ${ }^{\circledR}$, American Regent, Shirley, NY, USA); FCM, ferric carboxymaltose (Ferinject ${ }^{\circledR}$, Vifor (International) Ltd., St Gallen, Switzerland); FMX, ferumoxytol (Feraheme ${ }^{\circledR}$, AMAG Pharmaceuticals Inc., Lexington, MA, USA); LMWID, low molecular weight iron dextran (Infed ${ }^{\circledR}$, Watson Pharma Inc., Morristown, NJ, USA); control, saline treatment. Abbreviations: TBARs, thiobarbituric acid reactive substances; MDA, malondialdehyde. 


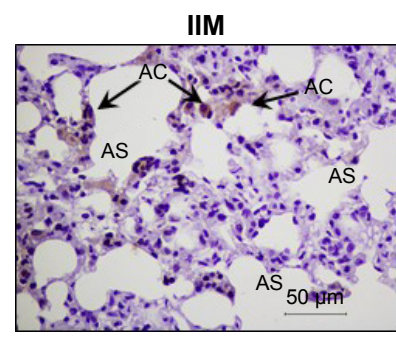

FMX

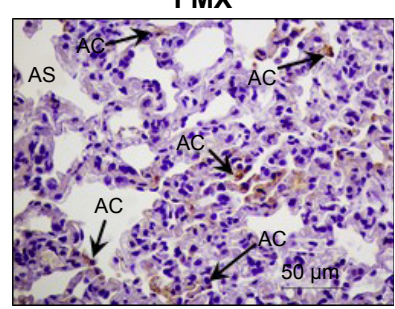

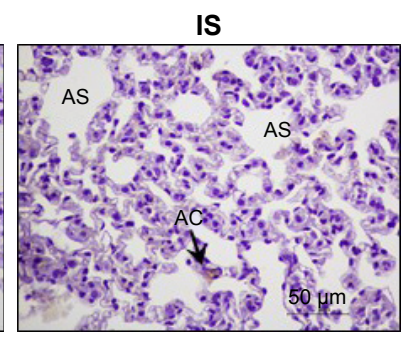

LMWID

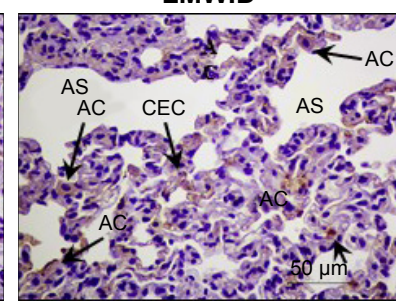

FCM

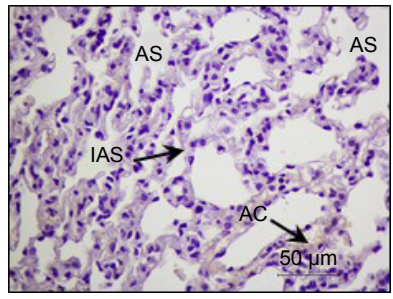

Control

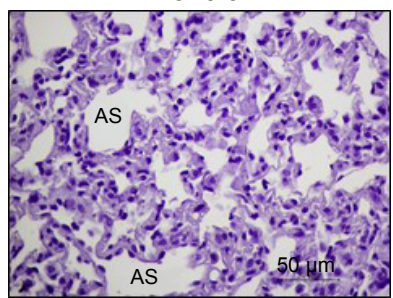

Figure I Nitrotyrosine immunohistochemistry.

Notes: Arrows indicate localization of nitrotyrosine immunostaining in lung of the different treatment groups. Positive staining (brown) is found in alveolar cells, primarily in groups treated with LMWID, FMX, and IIM. Cell types and tissue are indicated as capillary endothelial cells (CEC), alveolar sac (AS), alveolar cells (AC), and interalveolar septum (IAS). Original magnification $\times 200$. Scale bar $50 \mu \mathrm{m}$. IIM, iron isomaltoside 1000 (Monofer ${ }^{\circledR}$, Pharmacosmos A/S, Holbæk, Denmark); IS, iron sucrose (Venofer ${ }^{\circledR}$, American Regent, Shirley, NY, USA); FCM, ferric carboxymaltose (Ferinject ${ }^{\circledR}$, Vifor (International) Ltd., St Gallen, Switzerland); FMX, ferumoxytol (Feraheme ${ }^{\circledR}$, AMAG Pharmaceuticals Inc., Lexington, MA, USA); LMWID, low molecular weight iron dextran (Infed ${ }^{\circledR}$, Watson Pharma Inc., Morristown, NJ, USA); control, saline treatment.

lung tissue (Figure 2) showed significantly elevated levels of nitrotyrosine in the LMWID, FMX, and IIM groups compared to the control group, with highest levels in the LMWID- and FMX-treated rats.
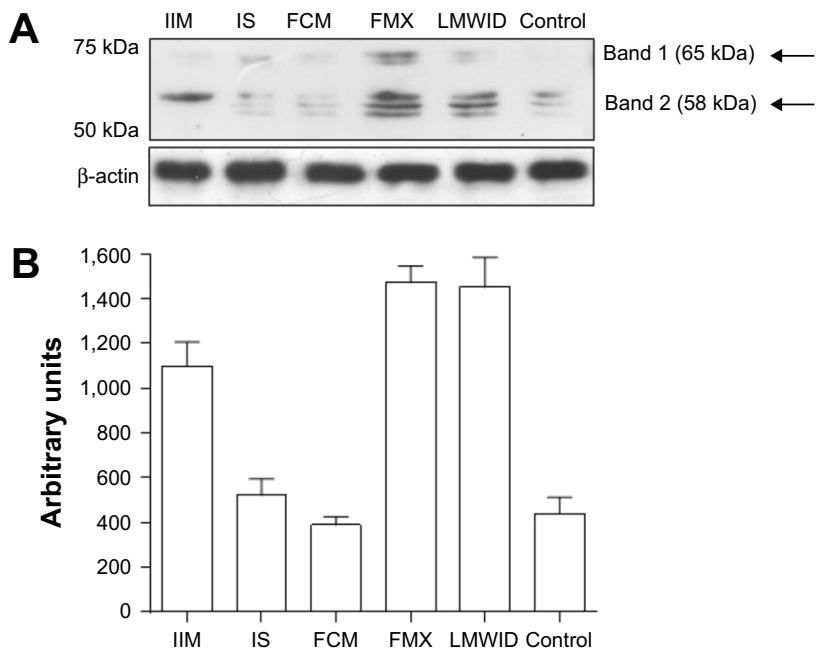

Figure 2 Nitrotyrosine Western blot analysis of lung homogenates.

Notes: (A) Nitrotyrosine immunoreactivity by Western blot technique for the different treatment groups. Arrows denote tyrosine nitration for proteins in the range of approximately $65 \mathrm{kDa}$ and $58 \mathrm{kDa}$. (B) Densitometric quantitation of tyrosine nitration for proteins resolved by Western blot shown in (A). Bars (with SD) represent total amount of tyrosine nitrated proteins as quantified by densitometry. Tyrosine nitration was significantly $(P<0.01)$ greater in LMWID-, FMX-, and IIM-treated rats compared to control, whereas this parameter was not different between FCM and IS treatment compared to controls. Tyrosine nitration was also significantly $(P<0.01)$ increased in the LMWID and FMX groups compared to all other intravenous iron groups. IIM, iron isomaltoside 1000 (Monofer ${ }^{\circledR}$, Pharmacosmos A/S, Holbæk, Denmark); IS, iron sucrose (Venofer ${ }^{\circledR}$, American Regent, Shirley, NY, USA); FCM, ferric carboxymaltose (Ferinject ${ }^{\circledR}$, Vifor (International) Ltd., St Gallen, Switzerland); FMX, ferumoxytol (Feraheme ${ }^{\circledR}$, AMAG Pharmaceuticals Inc., Lexington, MA, USA); LMWID, low molecular weight iron dextran (Infed ${ }^{\circledR}$, Watson Pharma Inc., Morristown, NJ, USA); control, saline treatment.

\section{Inflammatory response}

Immunohistochemistry of lung tissue sections indicated that levels of pro-inflammatory cytokines (TNF- $\alpha$ and IL-6) and relevant transcription factors (HIF- $1 \alpha$ and NF- $\mathrm{\kappa B}_{65}$ ) were significantly increased in animals treated with LMWID, FMX, and IIM compared to controls $(P<0.05)$ (Table 2). Staining of all four inflammation markers was highest in the LMWID group. Light microscopy indicated that staining was primarily localized to alveolar cells (Figures 3 and S1-S3).

Table 2 Inflammation parameters

\begin{tabular}{lllllll}
\hline Parameter & $\begin{array}{l}\text { IIM } \\
(\mathbf{n}=8)\end{array}$ & $\begin{array}{l}\text { IS } \\
(\mathbf{n}=8)\end{array}$ & $\begin{array}{l}\text { FCM } \\
(\mathbf{n}=8)\end{array}$ & $\begin{array}{l}\text { FMX } \\
(\mathbf{n}=8)\end{array}$ & $\begin{array}{l}\text { LMWID } \\
(\mathbf{n}=8)\end{array}$ & $\begin{array}{l}\text { Control } \\
(\mathbf{n}=8)\end{array}$ \\
\hline $\begin{array}{l}\text { HIF-I } \alpha \\
\text { (n/area) }\end{array}$ & $2.8 \pm 0.9$ & $0.8 \pm 0.2^{\mathrm{a}}$ & $0.6 \pm 0.2^{\mathrm{a}}$ & $3.0 \pm 0.6$ & $6.5 \pm 1.2^{\mathrm{b}}$ & $0.5 \pm 0.2^{\mathrm{a}}$ \\
$\begin{array}{l}\text { NF-kB } \\
\text { (n/area) }\end{array}$ & $5.3 \pm 0.7$ & $3.9 \pm 0.6^{\mathrm{a}}$ & $3.6 \pm 0.3^{\mathrm{a}}$ & $5.2 \pm 0.6$ & $6.7 \pm 1.2^{\mathrm{b}}$ & $2.5 \pm 0.8^{\mathrm{a}}$ \\
TNF- $\alpha$ & $3.6 \pm 0.9$ & $1.8 \pm 0.7^{\mathrm{a}}$ & $1.7 \pm 0.5^{\mathrm{a}}$ & $3.7 \pm 0.7$ & $5.5 \pm 1.1^{\mathrm{b}}$ & $1.0 \pm 0.5^{\mathrm{a}}$ \\
$(\% / a r e a)$ & & & & & & \\
IL-6 & $4.1 \pm 1.0$ & $3.4 \pm 0.6^{\mathrm{c}}$ & $3.0 \pm 0.5^{\mathrm{c}}$ & $4.1 \pm 0.7$ & $4.7 \pm 0.7$ & $2.4 \pm 0.5^{\mathrm{a}}$ \\
$\begin{array}{l}\text { (\%/area) } \\
\text { EDI cells } \\
\text { (n/area) }\end{array}$ & $2.6 \pm 0.4$ & $2.3 \pm 0.4^{\mathrm{c}}$ & $1.9 \pm 0.5^{\mathrm{c}}$ & $2.6 \pm 0.5$ & $2.8 \pm 0.3$ & $1.2 \pm 0.4^{\mathrm{a}}$ \\
$\begin{array}{l}\text { VEGF } \\
\text { (\%/area) }\end{array}$ & $1.3 \pm 0.3^{\mathrm{d}}$ & $1.2 \pm 0.2^{\mathrm{d}}$ & $1.0 \pm 0.3^{\mathrm{d}}$ & $1.7 \pm 0.2$ & $1.9 \pm 0.3$ & $0.8 \pm 0.3^{\mathrm{a}}$ \\
$\begin{array}{l}\text { VCAM-I } \\
\text { (\%/area) }\end{array}$ & $1.3 \pm 0.3$ & $0.7 \pm 0.1^{\mathrm{c}}$ & $0.6 \pm 0.1^{\mathrm{c}}$ & $2.8 \pm 0.6$ & $3.2 \pm 0.7$ & $0.5 \pm 0.2^{\mathrm{a}}$ \\
\hline
\end{tabular}

Notes: Data presented as mean \pm SD. ${ }^{a} P<0.05$ versus $L M W I D, F M X$, IIM, ${ }^{b} P<0.05$ versus FMX, IIM, ${ }^{c} P<0.05$ versus LMWID, ${ }^{d} p<0.05$ versus LMWID, FMX. IIM, iron isomaltoside 1000 (Monofer ${ }^{\circledR}$, Pharmacosmos A/S, Holbæk, Denmark); IS, iron sucrose $\left(\right.$ Venofer $^{\circledR}$, American Regent, Shirley, NY, USA); FCM, ferric carboxymaltose (Ferinject ${ }^{\circledR}$, Vifor (International) Ltd., St Gallen, Switzerland); FMX, ferumoxytol (Feraheme ${ }^{\circledR}$, AMAG Pharmaceuticals Inc., Lexington, MA, USA); LMWID, low molecular weight iron dextran (Infed $^{\circledR}$, Watson Pharma Inc., Morristown, NJ, USA); control, saline treatment. 


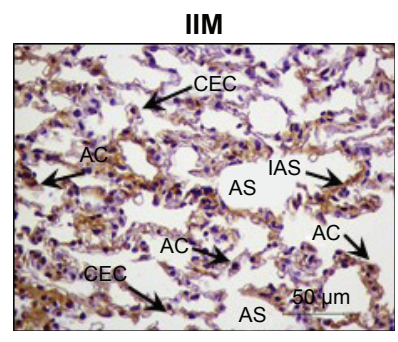

FMX

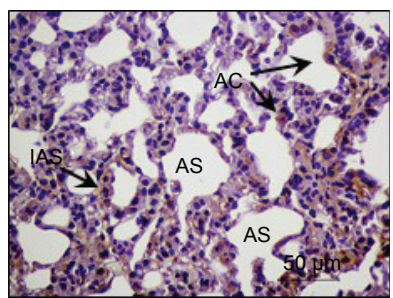

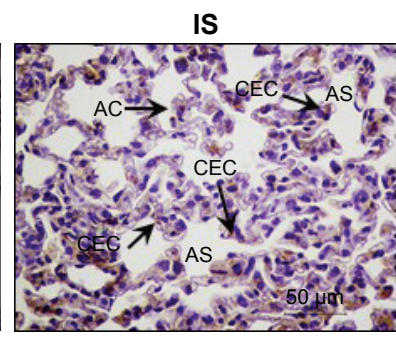

LMWID

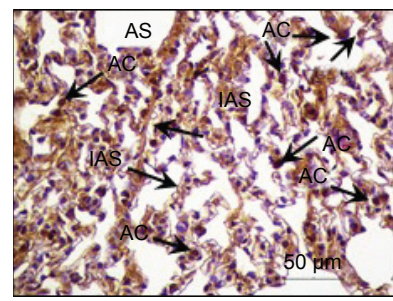

FCM

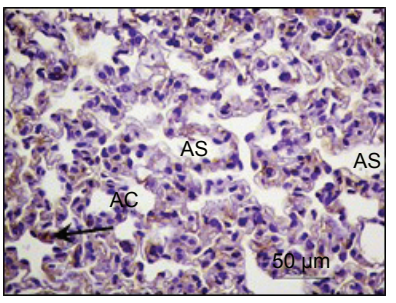

Control

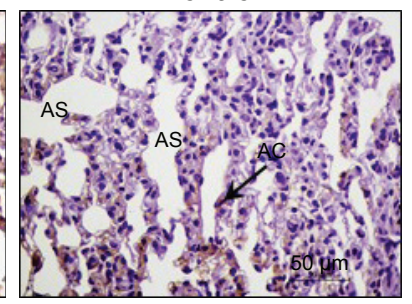

Figure 3 HIF-I $\alpha$ immunohistochemistry.

Notes: Arrows indicate localization of HIF-I $\alpha$ immunostaining in alveolar cells in lung of the different treatment groups. Positive staining (brown) is found in alveolar cells, interalveolar septum, and capillary endothelial cells, predominantly in the LMWID, FMX, and IIM treatment groups. Cell types and tissue are indicated as capillary endothelial cells (CEC), alveolar sac (AS), alveolar cells (AC), and interalveolar septum (IAS). Original magnification $\times 200$. Scale bar $50 \mu \mathrm{m}$. IIM, iron isomaltoside 1000 (Monofer ${ }^{\circledast}$, Pharmacosmos A/S, Holbæk, Denmark); IS, iron sucrose (Venofer ${ }^{\circledR}$, American Regent, Shirley, NY, USA); FCM, ferric carboxymaltose (Ferinject ${ }^{\circledR}$, Vifor (International) Ltd., St Gallen, Switzerland); FMX, ferumoxytol (Feraheme ${ }^{\oplus}$, AMAG Pharmaceuticals Inc., Lexington, MA, USA); LMWID, low molecular weight iron dextran (Infed ${ }^{\circledR}$, Watson Pharma Inc., Morristown, NJ, USA); control, saline treatment.

In agreement with the cytokine data, the number of cells with positive staining for the macrophage-specific CD68 (ED1) antigen was significantly increased in the LMWID, FMX, and IIM groups compared to controls $(P<0.05)$. Light microscopy indicated that ED1-positive macrophages were localized in the lung interstitium (Figure 4).

Compared to control animals, immunostaining for VCAM-1 and VEGF was significantly increased in animals treated with LMWID, FMX, and IIM $(P<0.05)$ (Table 2$)$.
VEGF and VCAM-1 immunostaining was present in endothelial and alveolar cells. Marked VCAM-1 staining was, additionally, present in lung interstitium, particularly in the LMWID and FMX groups (Figures S4 and S5).

\section{Tissue iron and ferritin}

Prussian blue staining and ferritin L chain immunostaining indicated that, compared to saline-treated control, iv administration of LMWID, IIM, and FMX to rats significantly

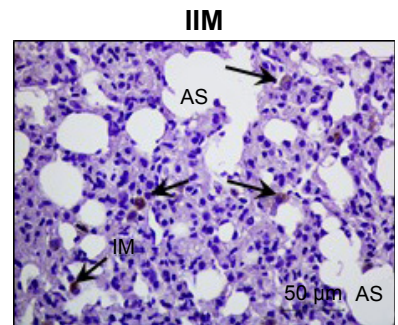

FMX

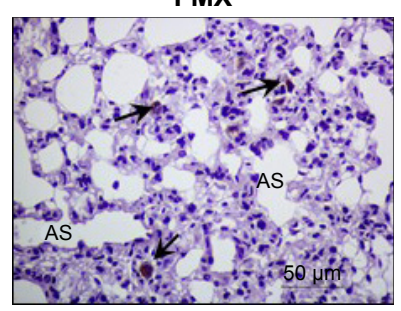

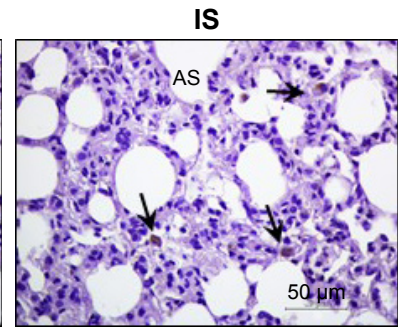

LMWID

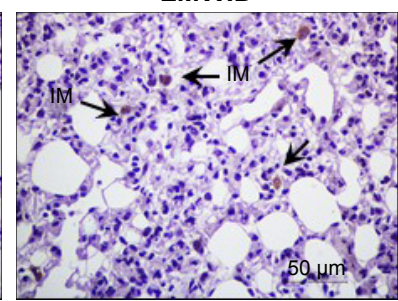

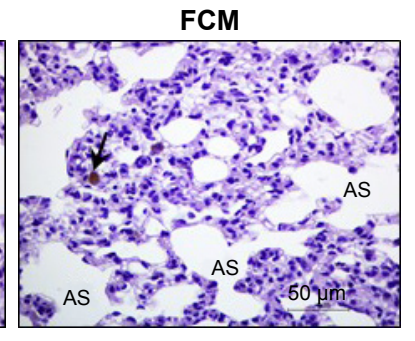

Control

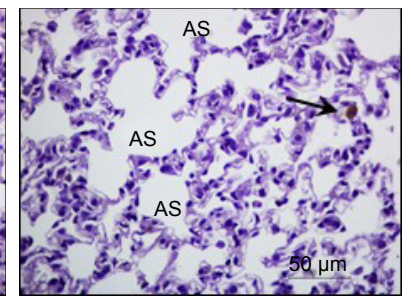

Figure 4 EDI immunohistochemistry.

Notes: Arrows indicate presence of EDI macrophages in lung interstitium in the different treatment groups. Numbers of positively stained (brown) cells (EDI macrophages) are greatest in the LMWID, FMX, and IIM treatment groups. Cell types and tissue are indicated as alveolar sac (AS), and interstitial macrophages (IM). Original magnification $\times 200$. Scale bar $50 \mu \mathrm{m}$. IIM, iron isomaltoside 1000 (Monofer $^{\circledR}$, Pharmacosmos A/S, Holbæk, Denmark); IS, iron sucrose (Venofer ${ }^{\circledR}$, American Regent, Shirley, NY, USA); FCM, ferric carboxymaltose (Ferinject ${ }^{\circledR}$, Vifor (International) Ltd., St Gallen, Switzerland); FMX, ferumoxytol (Feraheme ${ }^{\circledR}$, AMAG Pharmaceuticals Inc., Lexington, MA, USA); LMWID, low molecular weight iron dextran (Infed ${ }^{\circledR}$, Watson Pharma Inc., Morristown, NJ, USA); control, saline treatment. 
Table 3 Tissue iron and ferritin

\begin{tabular}{lllllll}
\hline Parameter & $\begin{array}{l}\text { IIM } \\
(\mathbf{n}=8)\end{array}$ & $\begin{array}{l}\text { IS } \\
(\mathbf{n}=8)\end{array}$ & $\begin{array}{l}\text { FCM } \\
(\mathbf{n}=8)\end{array}$ & $\begin{array}{l}\text { FMX } \\
(\mathbf{n}=8)\end{array}$ & $\begin{array}{l}\text { LMWID } \\
(\mathbf{n}=8)\end{array}$ & $\begin{array}{l}\text { Control } \\
(\mathbf{n}=8)\end{array}$ \\
\hline $\begin{array}{l}\text { Prussian blue } \\
\text { \%/area) }\end{array}$ & $\mathrm{I} .0 \pm 0.3^{\mathrm{b}}$ & $0.5 \pm 0.2$ & $0.3 \pm 0.2$ & $1.2 \pm 0.2^{\mathrm{b}}$ & $2.4 \pm 0.3^{\mathrm{a}}$ & $0.3 \pm 0.2$ \\
$\begin{array}{l}\text { L Ferritin } \\
\text { (\%/area) }\end{array}$ & $2.5 \pm 0.8^{\mathrm{b}}$ & $0.6 \pm 0.2$ & $0.7 \pm 0.2$ & $3.5 \pm 0.7^{\mathrm{c}}$ & $3.9 \pm 1.1^{\mathrm{c}}$ & $0.3 \pm 0.1$ \\
$\begin{array}{l}\text { H Ferritin } \\
\text { (\%/area) }\end{array}$ & $0.6 \pm 0.2$ & $0.5 \pm 0.1$ & $0.5 \pm 0.1$ & $0.8 \pm 0.2^{\mathrm{d}}$ & $\mathrm{I} .1 \pm 0.4^{\mathrm{c}}$ & $0.3 \pm 0.1$ \\
\hline
\end{tabular}

Notes: Data presented as mean $\pm S D$. ${ }^{a} P<0.01$ versus all groups, ${ }^{b} P<0.01$ versus IS, FCM, control, $c P<0.0$ I versus IS, FCM, IIM, control, $d P<0.0$ I versus control. IIM, iron isomaltoside 1000 (Monofer ${ }^{\circledast}$, Pharmacosmos A/S, Holbæk, Denmark); IS, iron sucrose (Venofer ${ }^{\circledast}$, American Regent, Shirley, NY, USA); FCM, ferric carboxymaltose (Ferinject ${ }^{\circledR}$, Vifor (International) Ltd., St Gallen, Switzerland); FMX, ferumoxytol (Feraheme ${ }^{\oplus}$, AMAG Pharmaceuticals Inc., Lexington, MA, USA); LMWID, low molecular weight iron dextran (Infed ${ }^{\circledR}$, Watson Pharma Inc., Morristown, NJ, USA); control, saline treatment.

increased iron deposition $(P<0.01)$ (Table 3, Figure 5). These parameters were not statistically different between FCM, IS, and control groups. Notably, Prussian blue staining was markedly elevated in LMWID-treated rats, whereas ferritin L chain levels were similarly elevated in LMWID-, FMX-, and IIM-treated rats. Ferritin $\mathrm{H}$ chain levels were only modestly elevated by LMWID and FMX treatment. Prussian blue staining was mainly localized in capillary endothelial cells, alveolar cells, interstitial macrophages (IMs), and interalveolar septum (Figure 5). Ferritin L and $\mathrm{H}$ chain immunostaining was localized, predominantly, in alveolar cells (Figures S6 and S7). FCM and IS were not associated with significant iron deposition in the lung compared to control.

\section{Discussion}

Following administration of various iv iron products (LMWID, FMX, IIM, FCM, and IS) or saline to non-anemic healthy rats, we identified product-dependent toxicological effects such as oxidative/nitrosative stress, inflammation, and iron deposition in the lung of treated rats. Compared to saline control, administration of LMWID, FMX, and IIM was associated with statistically significant increases in virtually all measured parameters; LMWID treatment demonstrated the greatest effects on measured toxicological parameters. Increases in markers of lipid peroxidation (MDA) and protein nitration (nitrotyrosine) were consistent with increased activity of antioxidant enzymes (catalase, CuZn-SOD, GPx) and decreases in antioxidative capacity (GSH:GSSG ratio). In line with oxidative stress being a trigger of inflammation, ${ }^{25-28}$ levels of inflammatory pathway transcription factors (NF- $\mathrm{\kappa B}$, HIF- $1 \alpha$ ), inflammatory cytokines (TNF- $\alpha$, IL-6), adhesion molecules (VCAM-1), and markers of macrophage infiltration (ED-1) were increased. Changes in measured parameters were generally modest in FCM- and IS-treated rats compared to animals receiving saline. This suggests that FCM and IS have a low propensity to induce lung inflammation. Notably, increases in oxidative stress markers aligned with increases in iron deposition.

While some studies report methods for direct measurement of reactive oxygen/nitrogen species (ROS/RNS), surrogate markers of oxidative/nitrosative stress are also

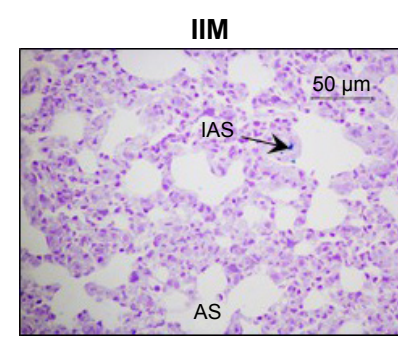

FMX

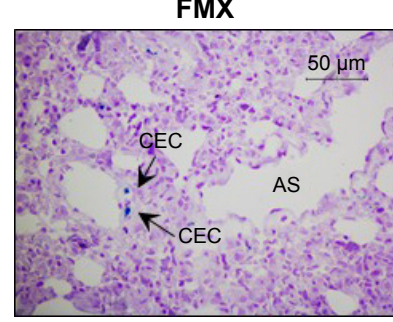

IS

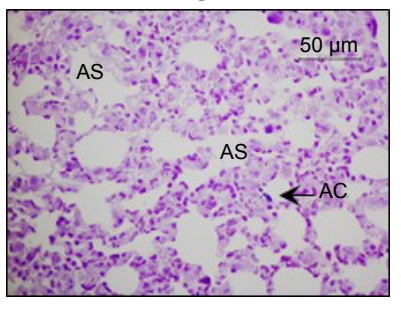

LMWID

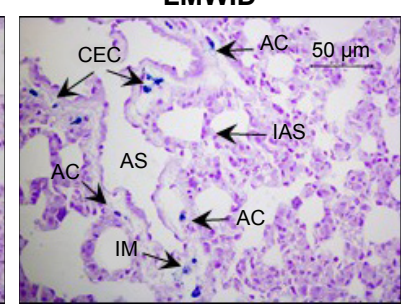

FCM

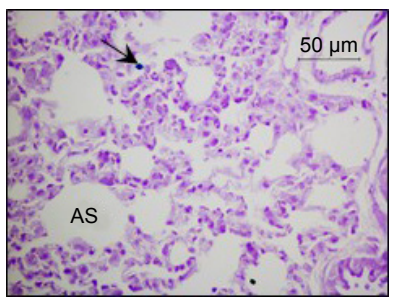

Control

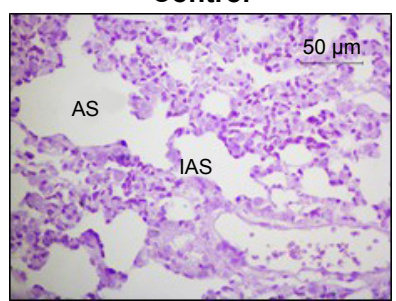

Figure 5 Prussian blue staining.

Notes: Identification of iron deposits in lung at the end of study. Cell types and tissue are indicated as capillary endothelial cells (CEC), alveolar sac (AS), alveolar cells (AC), interstitial macrophages (IM), and interalveolar septum (IAS). Arrows denote positive staining for iron deposits (blue) predominantly in the group treated with LMWID (CEC, AC, IM, IAS), with moderate amounts in the FMX (CEC) and IIM (IAS) treatment groups. IS, FCM, and control groups show similar low level staining. Original magnification $\times 200$. Scale bar $50 \mu \mathrm{m}$. IIM, iron isomaltoside 1000 (Monofer ${ }^{\circledR}$, Pharmacosmos A/S, Holbæk, Denmark); IS, iron sucrose (Venofer ${ }^{\circledR}$, American Regent, Shirley, NY, USA); FCM, ferric carboxymaltose (Ferinject ${ }^{\circledR}$, Vifor (International) Ltd., St Gallen, Switzerland); FMX, ferumoxytol (Feraheme ${ }^{\circledR}$, AMAG Pharmaceuticals Inc., Lexington, MA, USA); LMWID, low molecular weight iron dextran (Infed ${ }^{\circledR}$, Watson Pharma Inc., Morristown, NJ, USA); control, saline treatment. 
widely established and have been measured in the present study. A typical surrogate marker of oxidative stress is MDA, a product formed when polyunsaturated lipids are degraded by ROS. A typical surrogate marker for nitrosative stress is nitrotyrosine formation, a consequence of the reaction between nitric oxide (NO) and a superoxide anion to form the highly reactive and damaging peroxynitrite (ONOO-) anion, which in turn reacts with tyrosine residues in proteins.

Using a similar model, a previous non-clinical study measured nitrotyrosine and dinitrophenyl in lung tissue after iv iron treatment. ${ }^{21}$ Compared to our study, the iron dose was substantially lower ( $1 \mathrm{mg} / \mathrm{kg}$, five times weekly), corresponding to the maximum single dose of FG rather than the maximum single dose of more stable iv iron compounds $(20 \mathrm{mg} / \mathrm{kg})$. Nonetheless, at this low dose, significant effects on nitrosative stress were detected in lung, liver, heart, and kidney.

Release of so-called "labile" iron from iv iron complexes and its unphysiological binding to transferrin and other proteins (referred to as NTBI) is associated with oxidative stress. ${ }^{14}$ Labile iron release is highest in complexes of low or moderate stability (FG and IS) but considerably lower in stable complexes (LMWID, IIM, FMX, and FCM). ${ }^{11,13,17}$ However, in the present study, LMWID, IIM, and FMX, but not FCM were associated with significant induction of oxidative/nitrosative stress in the lung. This is consistent with studies that evaluated these parameters in the liver, kidney, and heart. ${ }^{17,18}$ Therefore, in addition to labile iron release, other physicochemical properties must contribute to oxidative stress.

Differences in biodegradability of carbohydrate ligands may explain this observation. ${ }^{14}$ While the carboxymaltose shell of FCM can be degraded by endogenous $\alpha$-amylase, the depolymerization of dextran requires other mechanisms that depend on dextran structure or the production of $\mathrm{O}_{2}$ and NO radicals. Furthermore, dextran-based ligands can impart longer half-lives on iron complexes.9,17,21 Together, these factors may result in iron accumulation in cells of the RES, increased generation of ROS/RNS, formation of hemosiderin, and retention of ferritin in macrophages. ${ }^{14,29}$

Increased Prussian blue staining in capillary endothelial cells, alveolar cells, IMs, and the interalveolar septum was particularly prominent in LMWID- and FMX-treated animals. Increased ferritin $\mathrm{L}$ and $\mathrm{H}$ chain levels were seen in alveolar cells of LMWID-, IIM-, and FMX-treated animals. This indicates product-dependent iron deposition in both the vascular system and lung tissue. Notably, accumulation of iron and inflammatory response was most evident in alveolar cells. Considering that nano-sized $\mathrm{Fe}_{2} \mathrm{O}_{3}$ particles increase microvascular permeability in lung epithelia, it is reasonable to suggest that iron from capillary endothelial cells may be rapidly accessed by alveolar epithelial cells. ${ }^{30}$ As described previously, hepcidin does not appear to modify cellular iron metabolism in the lung. Greater supply of iron may, therefore, result in iron overload in alveolar cells. ${ }^{31}$ Additionally, several in vitro studies indicate a positive correlation between iron concentration and chemokine release from alveolar epithelial cells. Collectively, this information suggests that alveolar cells may be more susceptible to iron uptake and subsequent inflammatory insult. Signs of thickening in the interalveolar septum may suggest formation of local edema or cellular infiltration.

Alveolar macrophages (AMs) defend against airway infection and airborne particles. ${ }^{32}$ AMs are highly active in metal transport and can accumulate high concentrations of iron that overwhelm ferritin storage and lead to oxidative injury. ${ }^{33}$ Due to low levels of ferritin H-subunits, AMs are themselves highly susceptible to oxidative/nitrosative stress. ${ }^{34}$ Our findings show increased numbers of interstitial ED1 macrophages in animals treated with LMWID, IIM, and FMX. This may indicate an inflammatory response initiated by tissue iron deposition and ensuing ROS/RNS production.

In rats, AMs but not IMs are reported to be ED1-positive. ${ }^{35}$ Without additional phenotyping, we cannot infer the origin of the interstitial ED1-positive macrophages detected in our study. AMs may have been derived from resident macrophages or from cells that migrated into the lung in response to iron-induced increases in VCAM-1 or increased capillary leakage mediated by VEGF. In inflammatory lung disorders like COPD, Prussian blue-positive AMs are detected in lung tissue, and AM iron levels correlate with disease severity. ${ }^{36}$

In the lung, inflammation can exacerbate iron-induced oxidative/nitrosative stress by mechanisms that include increased iron uptake (eg, TNF- $\alpha$ induced upregulation of DMT-1 in bronchial epithelial cells) and increased iron retention (eg, IL-6 induced hepcidin production by airway epithelial cells and AMs). ${ }^{37-39}$ Therefore, lung iron deposition can trigger synergistic pathways that may perpetuate inflammation.

In terms of functional sequelae, it is possible that inflammation in the alveolar septum, as seen in our study, might impair normal bi-directional gas exchange between the alveolar space and capillary bed. 
The primary objective of our study was to assess toxicological differences, that may relate to safety differences, between iv iron products. As such, distinctions between the non-clinical model used here and the clinical setting include the use of non-iron deficient, non-anemic animals and iron doses that exceed those used clinically. Despite these differences, findings from this study, and other rodent studies, demonstrate changes in oxidative stress biomarkers similar to those observed in the clinical setting. ${ }^{14}$

In summary, repeat-dose administration of LMWID, FMX, and IIM to healthy rats was associated with significant increases in lung oxidative/nitrosative stress, inflammation, iron deposition, and numbers of interstitial ED1-positive macrophages compared to saline-treated controls. In contrast, FCM and IS administration was not associated with increases in most of the assessed parameters. The relevance of these findings to clinical safety requires further investigation.

\section{Acknowledgments}

The study was financially supported by Vifor (International) Ltd. Scientific writing support was provided by Lee Mizzen, Taija Koskenkorva-Frank (both Vifor Pharma) and Walter Fürst (SFL Regulatory Affairs \& Scientific Communication, funded by Vifor Pharma). Support for graphics and illustrations were provided by Tracey Nichols (Tracey Nichols Graphic Design Ltd.).

\section{Disclosure}

Jorge E Toblli has received research grants and consultancy fees from Vifor (International) Ltd., Switzerland. Gabriel Cao, Jorge F Giani, Fernando P Dominici, and Margarita Angerosa have no conflicts of interest to report.

\section{References}

1. Macdougall IC, Geisser P. Use of intravenous iron supplementation in chronic kidney disease: an update. Iran J Kidney Dis. 2013;7(1):9-22.

2. Silverberg DS, Wexler D, Blum M, Iaina A. The cardio renal anemia syndrome: correcting anemia in patients with resistant congestive heart failure can improve both cardiac and renal function and reduce hospitalizations. Clin Nephrol. 2003;60 Suppl 1:S93-S102.

3. Wilson A, Reyes E, Ofman J. Prevalence and outcomes of anemia in inflammatory bowel disease: a systematic review of the literature. Am J Med. 2004;116 Suppl 7A:44S-49S.

4. Aapro M, Osterborg A, Gascon P, Ludwig H, Beguin Y. Prevalence and management of cancer-related anaemia, iron deficiency and the specific role of i.v. iron. Ann Oncol. 2012;23(8):1954-1962.

5. Bodnar LM, Cogswell ME, Scanlon KS. Low income postpartum women are at risk of iron deficiency. J Nutr. 2002;132(8):2298-2302.

6. Beris P, Munoz M, Garcia-Erce JA, Thomas D, Maniatis A, Van der Linden P. Perioperative anaemia management: consensus statement on the role of intravenous iron. Br J Anaesth. 2008;100(5):599-604.

7. Morrison J, Patel ST, Watson W, Zaidi QR, Mangione A, Goss TF. Assessment of the prevalence and impact of anemia on women hospitalized for gynecologic conditions associated with heavy uterine bleeding. J Reprod Med. 2008;53(5):323-330.
8. Macdougall IC. Strategies for iron supplementation: oral versus intravenous. Kidney Int Suppl. 1999;69:S61-S66.

9. Geisser P, Burckhardt S. The pharmacokinetics and pharmacodynamics of iron preparations. Pharmaceutics. 2011;3(1):12-33.

10. European Medicines Agency. Rienso. Withdrawal of the Marketing Authorisation in the European Union. EMA; 2015. Available from: www.ema.europa.eu/docs/en_GB/document_library/Public_ statement/2015/07/WC500189474.pdf. Accessed July 13, 2017.

11. Jahn MR, Andreasen HB, Futterer S, et al. A comparative study of the physicochemical properties of iron isomaltoside 1000 (Monofer), a new intravenous iron preparation and its clinical implications. Eur J Pharm Biopharm. 2011;78(3):480-491.

12. Locatelli F, Del Vecchio L. New erythropoiesis-stimulating agents and new iron formulations. Contrib Nephrol. 2011;171:255-260.

13. Neiser S, Rentsch D, Dippon U, et al. Physico-chemical properties of the new generation IV iron preparations ferumoxytol, iron isomaltoside 1000 and ferric carboxymaltose. Biometals. 2015;28(4):615-635.

14. Koskenkorva-Frank TS, Weiss G, Koppenol WH, Burckhardt S. The complex interplay of iron metabolism, reactive oxygen species, and reactive nitrogen species: insights into the potential of various iron therapies to induce oxidative and nitrosative stress. Free Radic Biol Med. 2013;65C:1174-1194.

15. Andrews NC, Schmidt PJ. Iron homeostasis. Annu Rev Physiol. 2007; 69:69-85.

16. Evans RW, Rafique R, Zarea A, et al. Nature of non-transferrin-bound iron: studies on iron citrate complexes and thalassemic sera. J Biol Inorg Chem. 2008;13(1):57-74.

17. Toblli JE, Cao G, Oliveri L, Angerosa M. Evaluation of toxicity and oxidative stress induced by intravenous iron isomaltoside 1000 in a nonclinical model. Arzneimittelforschung. 2011;61(10):553-565.

18. Toblli JE, Cao G, Oliveri L, Angerosa M. Assessment of the extent of oxidative stress induced by intravenous ferumoxytol, ferric carboxymaltose, iron sucrose and iron dextran in a nonclinical model. Arzneimittelforschung. 2011;61(7):399-410.

19. Toblli JE, Cao G, Giani JF, Dominici FP, Angerosa M. Nitrosative stress and apoptosis by intravenous ferumoxytol, iron isomaltoside 1000, iron dextran, iron sucrose, and ferric carboxymaltose in a nonclinical model. Drug Res (Stuttg). 2015;65(7):354-360.

20. Toblli JE, Cao G, Oliveri L, Angerosa M. Comparison of oxidative stress and inflammation induced by different intravenous iron sucrose similar preparations in a rat model. Inflamm Allergy Drug Targets. 2012;11(1):66-78.

21. Bailie GR, Schuler C, Leggett RE, et al. Oxidative effect of several intravenous iron complexes in the rat. Biometals. 2013;26(3): 473-478.

22. Toblli JE, Cao G, Oliveri L, Angerosa M. Differences between original intravenous iron sucrose and iron sucrose similar preparations. Arzneimittelforschung. 2009;59(4):176-190.

23. Giani JF, Gironacci MM, Munoz MC, Pena C, Turyn D, Dominici FP. Angiotensin-(1 7) stimulates the phosphorylation of JAK2, IRS-1 and Akt in rat heart in vivo: role of the AT1 and Mas receptors. Am J Physiol Heart Circ Physiol. 2007;293(2):H1154-H1163.

24. Munoz MC, Argentino DP, Dominici FP, Turyn D, Toblli JE. Irbesartan restores the in-vivo insulin signaling pathway leading to Akt activation in obese Zucker rats. J Hypertens. 2006;24(8):1607-1617.

25. Forsythe JA, Jiang BH, Iyer NV, et al. Activation of vascular endothelial growth factor gene transcription by hypoxia-inducible factor $1 \mathrm{Mol}$ Cell Biol. 1996;16(9):4604-4613.

26. Kiriakidis S, Andreakos E, Monaco C, Foxwell B, Feldmann M, Paleolog E. VEGF expression in human macrophages is NF-kappaBdependent: studies using adenoviruses expressing the endogenous NF-kappaB inhibitor IkappaBalpha and a kinase-defective form of the IkappaB kinase 2. J Cell Sci. 2003;116(Pt 4):665-674.

27. Rahman I, MacNee W. Oxidative stress and regulation of glutathione in lung inflammation. Eur Respir J. 2000;16(3):534-554.

28. Santus P, Corsico A, Solidoro P, Braido F, Di Marco F, Scichilone N. Oxidative stress and respiratory system: pharmacological and clinical reappraisal of N-acetylcysteine. COPD. 2014;11(6):705-717. 
29. Kurz T, Terman A, Gustafsson B, Brunk UT. Lysosomes in iron metabolism, ageing and apoptosis. Histochem Cell Biol. 2008;129(4): 389-406.

30. Zhu MT, Feng WY, Wang B, et al. Comparative study of pulmonary responses to nano- and submicron-sized ferric oxide in rats. Toxicology. 2008;247(2-3):102-111.

31. Giorgi G, D’Anna MC, Roque ME. Iron homeostasis and its disruption in mouse lung in iron deficiency and overload. Exp Physiol. 2015; 100(10):1199-1216.

32. Aggarwal NR, King LS, D'Alessio FR. Diverse macrophage populations mediate acute lung inflammation and resolution. Am J Physiol Lung Cell Mol Physiol. 2014;306(8):L709-L725.

33. Ghio AJ. Disruption of iron homeostasis and lung disease. Biochim Biophys Acta. 2009;1790(7):731-739.

34. Mateos F, Brock JH, Perez-Arellano JL. Iron metabolism in the lower respiratory tract. Thorax. 1998;53(7):594-600.

35. van der Brugge-Gamelkoorn GJ, Dijkstra CD, Sminia T. Characterization of pulmonary macrophages and bronchus-associated lymphoid tissue (BALT) macrophages in the rat. An enzyme-cytochemical and immunocytochemical study. Immunobiology. 1985;169(5):553-562.
36. Philippot Q, Deslee G, Adair-Kirk TL, et al. Increased iron sequestration in alveolar macrophages in chronic obstructive pulmonary disease. PLoS One. 2014;9(5):e96285.

37. Wang X, Garrick MD, Yang F, Dailey LA, Piantadosi CA, Ghio AJ. TNF, IFN-gamma, and endotoxin increase expression of DMT1 in bronchial epithelial cells. Am J Physiol Lung Cell Mol Physiol. 2005;289(1):L24-L33.

38. Frazier MD, Mamo LB, Ghio AJ, Turi JL. Hepcidin expression in human airway epithelial cells is regulated by interferon-gamma. Respir Res. 2011;12:100.

39. Nguyen NB, Callaghan KD, Ghio AJ, Haile DJ, Yang F. Hepcidin expression and iron transport in alveolar macrophages. Am J Physiol Lung Cell Mol Physiol. 2006;291(3):L417-L425. 


\section{Supplementary materials}

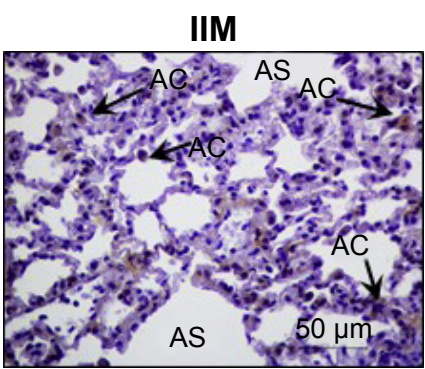

FMX

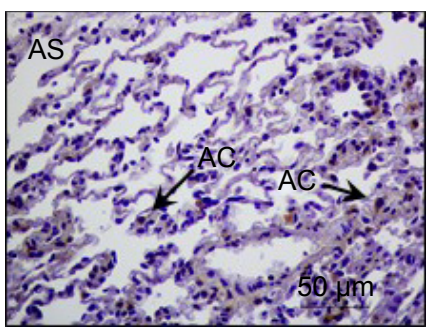

IS

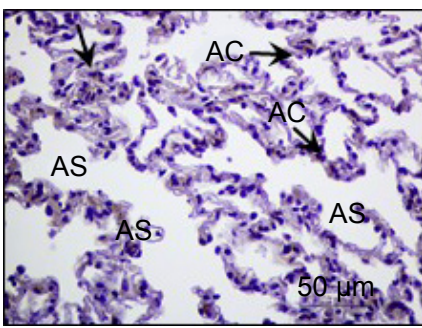

LMWID

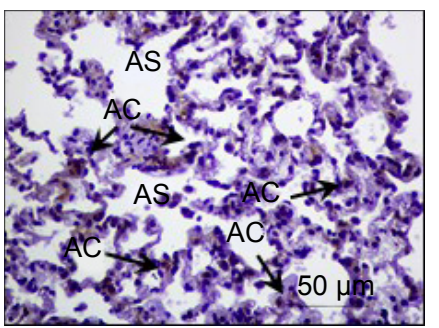

FCM

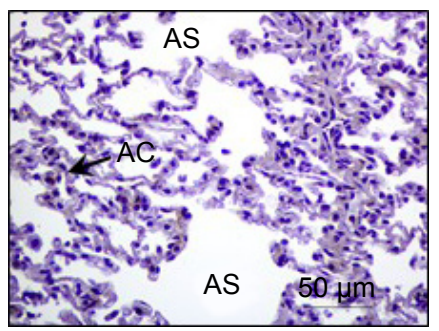

Control

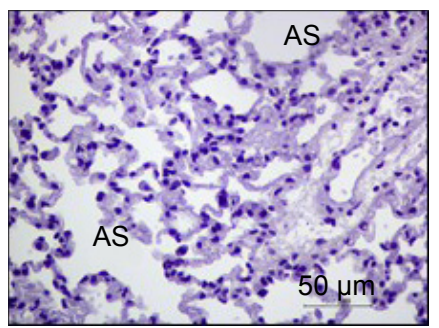

Figure SI NF- $\mathrm{KB}_{65}$ immunohistochemistry.

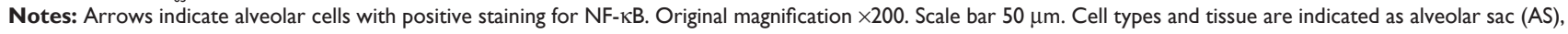
and alveolar cells (AC). IIM, iron isomaltoside 1000 (Monofer ${ }^{\circledR}$, Pharmacosmos A/S, Holbæk, Denmark); IS, iron sucrose (Venofer ${ }^{\circledR}$, American Regent, Shirley, NY, USA); FCM, ferric carboxymaltose (Ferinject ${ }^{\circledR}$, Vifor (International) Ltd., St Gallen, Switzerland); FMX, ferumoxytol (Feraheme ${ }^{\circledR}$, AMAG Pharmaceuticals Inc., Lexington, MA, USA); LMWID, low molecular weight iron dextran (Infed ${ }^{\circledR}$, Watson Pharma Inc., Morristown, NJ, USA); control, saline treatment.

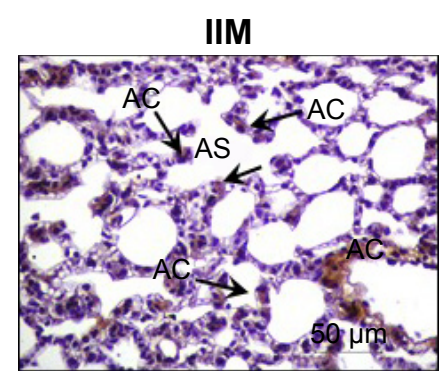

FMX

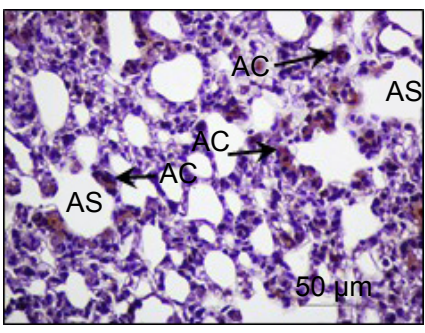

IS

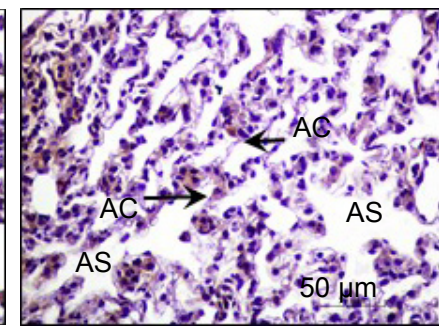

LMWID

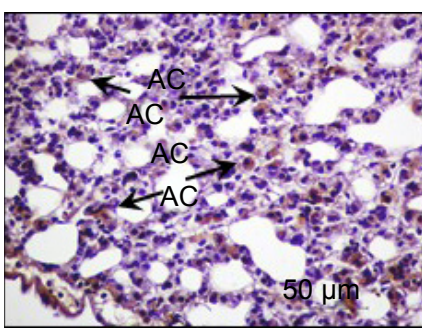

FCM

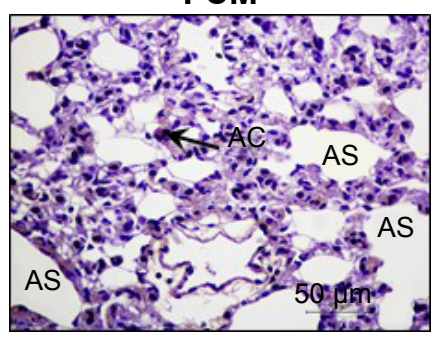

Control

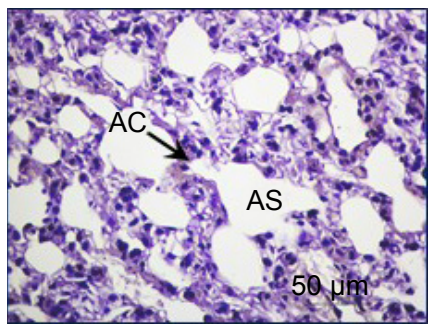

Figure S2 TNF- $\alpha$ immunohistochemistry.

Notes: Arrows indicate localization of TNF- $\alpha$ in alveolar cells. Original magnification $\times 200$. Scale bar $50 \mu \mathrm{m}$. Cell types and tissue are indicated as alveolar sac (AS), and alveolar cells (AC). IIM, iron isomaltoside 1000 (Monofer $^{\circledR}$, Pharmacosmos A/S, Holbæk, Denmark); IS, iron sucrose (Venofer ${ }^{\circledR}$, American Regent, Shirley, NY, USA); FCM, ferric carboxymaltose (Ferinject ${ }^{\circledR}$, Vifor (International) Ltd., St Gallen, Switzerland); FMX, ferumoxytol (Feraheme ${ }^{\circledR}$, AMAG Pharmaceuticals Inc., Lexington, MA, USA); LMWID, low molecular weight iron dextran (Infed ${ }^{\circledR}$, Watson Pharma Inc., Morristown, NJ, USA); control, saline treatment. 

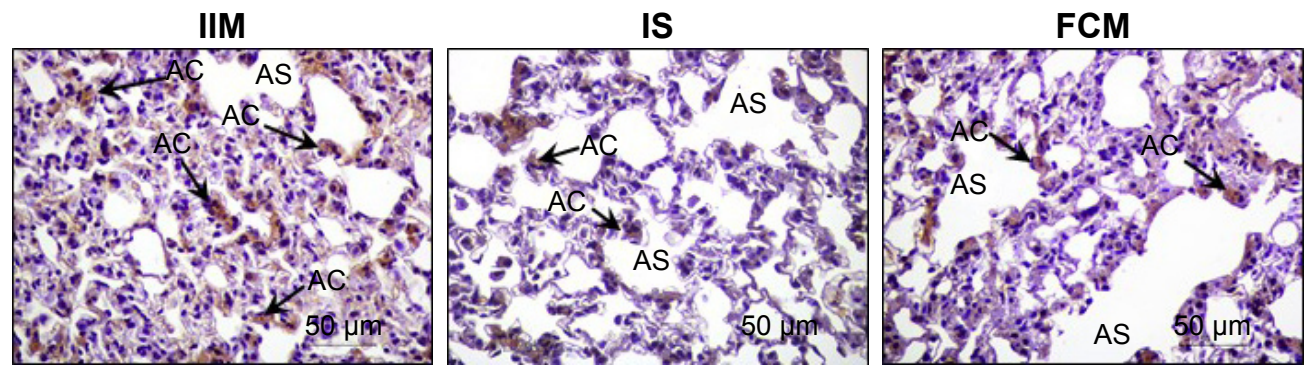

FMX

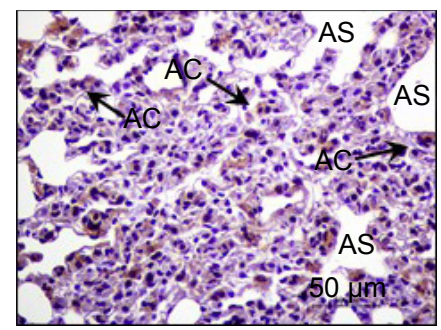

LMWID

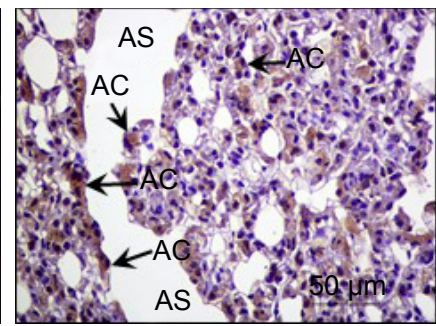

\section{Control}

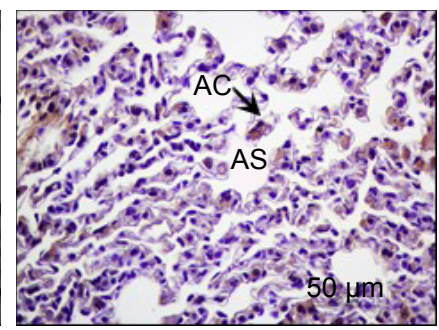

Figure S3 IL-6 immunohistochemistry.

Notes: Arrows indicate localization of IL-6 in alveolar cells. Original magnification $\times 200$. Scale bar $50 \mu \mathrm{m}$. Cell types and tissue are indicated as alveolar sac (AS), and alveolar cells (AC). IIM, iron isomaltoside 1000 (Monofer ${ }^{\circledR}$, Pharmacosmos A/S, Holbæk, Denmark); IS, iron sucrose (Venofer ${ }^{\circledR}$, American Regent, Shirley, NY, USA); FCM, ferric carboxymaltose (Ferinject ${ }^{\circledR}$, Vifor (International) Ltd., St Gallen, Switzerland); FMX, ferumoxytol (Feraheme ${ }^{\circledR}$, AMAG Pharmaceuticals Inc., Lexington, MA, USA); LMWID, low molecular weight iron dextran (Infed ${ }^{\circledR}$, Watson Pharma Inc., Morristown, NJ, USA); control, saline treatment.

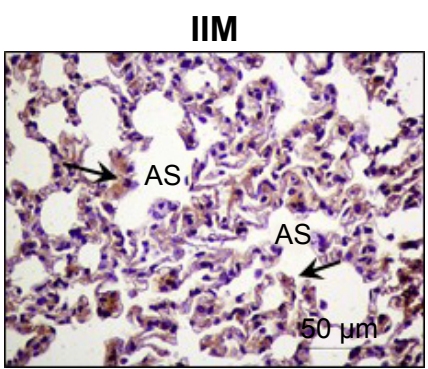

FMX

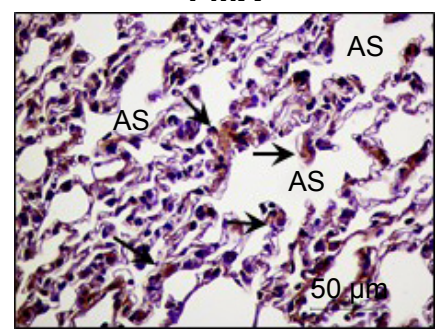

IS

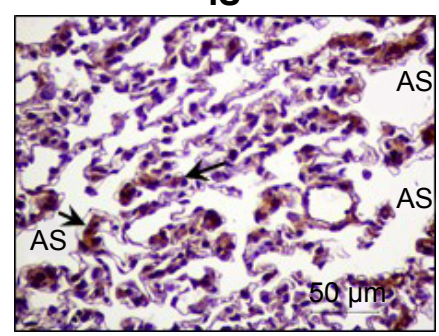

LMWID

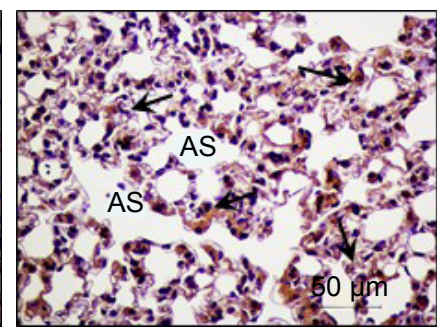

FCM

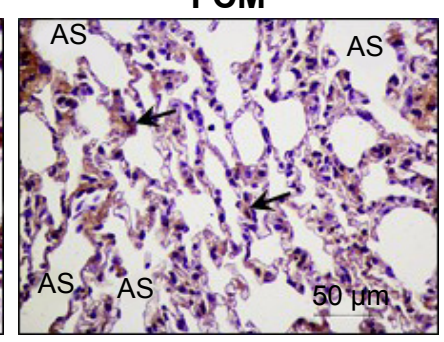

Control

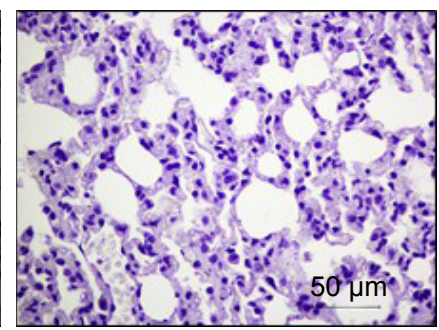

Figure S4 VEGF immunohistochemistry.

Notes: Arrows indicate presence of VEGF not only in endothelial cells' localization but also in alveolar cells in the different groups. Original magnification $\times 200$. Scale bar $50 \mu \mathrm{m}$. Cell types and tissue are indicated as alveolar sac (AS). IIM, iron isomaltoside 1000 (Monofer ${ }^{\circledR}$, Pharmacosmos A/S, Holbæk, Denmark); IS, iron sucrose (Venofer ${ }^{\circledR}$, American Regent, Shirley, NY, USA); FCM, ferric carboxymaltose (Ferinject ${ }^{\circledR}$, Vifor (International) Ltd., St Gallen, Switzerland); FMX, ferumoxytol (Feraheme ${ }^{\circledR}$, AMAG Pharmaceuticals Inc., Lexington, MA, USA); LMWID, low molecular weight iron dextran (Infed ${ }^{\circledR}$, Watson Pharma Inc., Morristown, NJ, USA); control, saline treatment. 
IIM

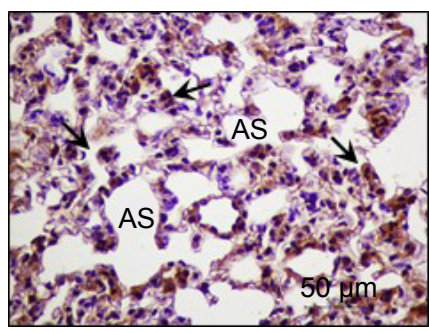

FMX

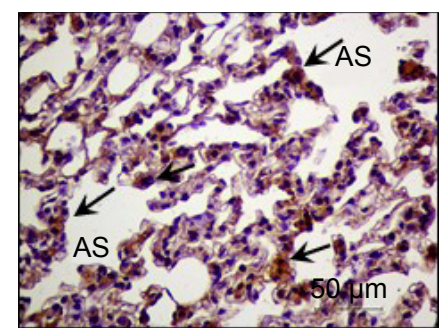

IS

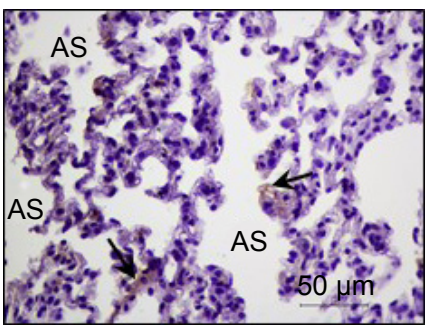

LMWID

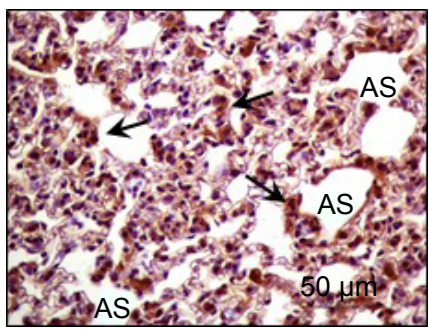

FCM

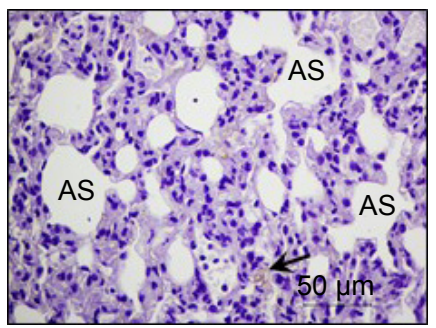

Control

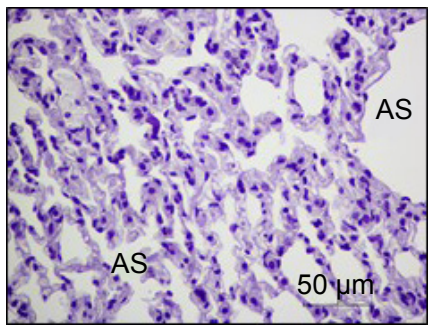

Figure S5 VCAM-I immunohistochemistry.

Notes: Arrows indicate presence of VCAM in endothelial cells, alveolar cells, and also in lung interstitium in the different groups. Original magnification $\times 200$. Scale bar

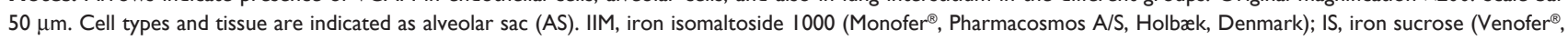
American Regent, Shirley, NY, USA); FCM, ferric carboxymaltose (Ferinject ${ }^{\circledR}$, Vifor (International) Ltd., St Gallen, Switzerland); FMX, ferumoxytol (Feraheme ${ }^{\circledR}$, AMAG Pharmaceuticals Inc., Lexington, MA, USA); LMWID, low molecular weight iron dextran (Infed ${ }^{\circledR}$, Watson Pharma Inc., Morristown, NJ, USA); control, saline treatment.

IIM

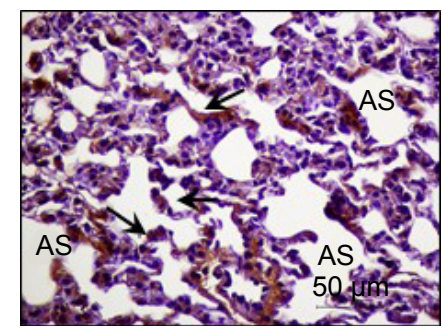

FMX

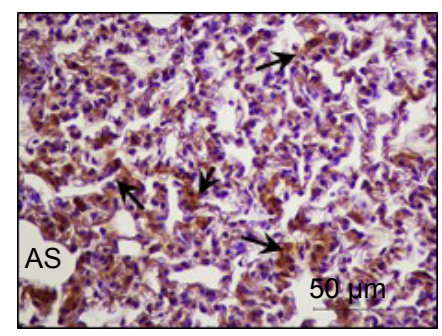

IS

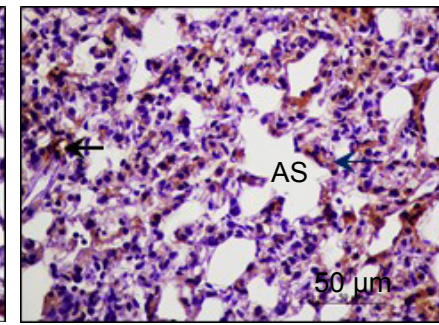

LMWID

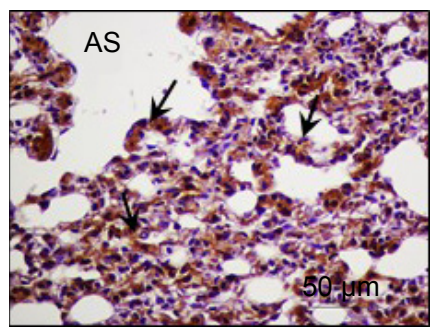

FCM

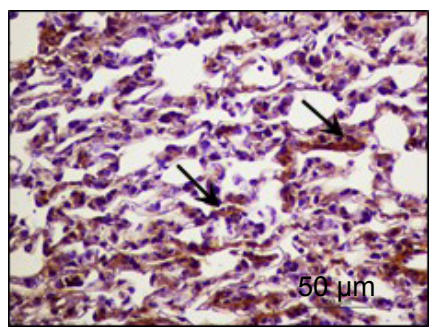

Control

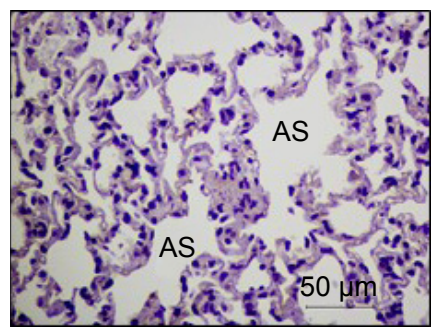

Figure S6 Ferritin L chain immunohistochemistry.

Notes: Arrows indicate localization of ferritin $L$ in alveolar cells and other cells of the different groups. Original magnification $\times 200$. Scale bar $50 \mu m$. Cell types and tissue are indicated as alveolar sac (AS). IIM, iron isomaltoside 1000 (Monofer ${ }^{\circledR}$, Pharmacosmos A/S, Holbæk, Denmark); IS, iron sucrose (Venofer ${ }^{\circledR}$, American Regent, Shirley, NY, USA); FCM, ferric carboxymaltose (Ferinject ${ }^{\circledR}$, Vifor (International) Ltd., St Gallen, Switzerland); FMX, ferumoxytol (Feraheme ${ }^{\circledR}$, AMAG Pharmaceuticals Inc., Lexington, MA, USA); LMWID, low molecular weight iron dextran (Infed ${ }^{\circledR}$, Watson Pharma Inc., Morristown, NJ, USA); control, saline treatment. 


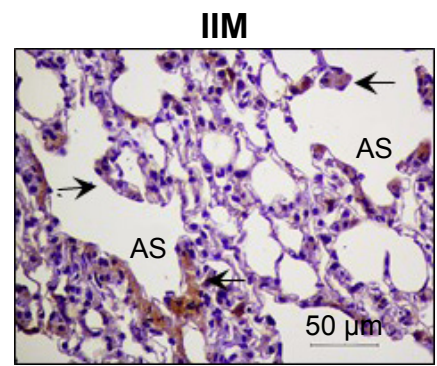

FMX

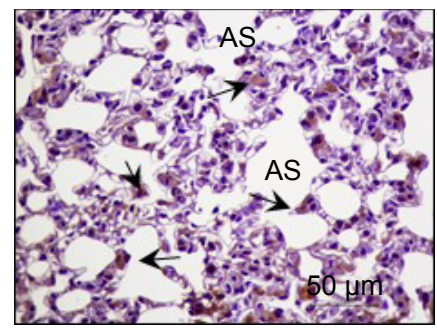

IS

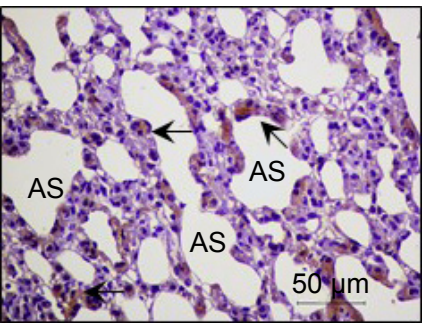

LMWID

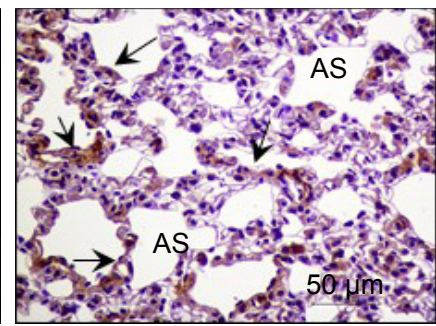

FCM

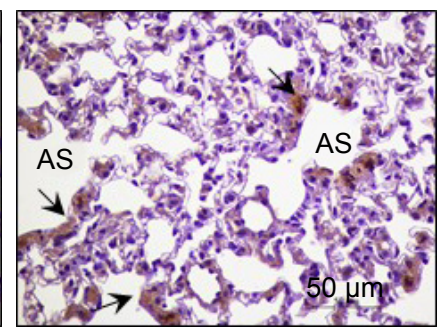

Control

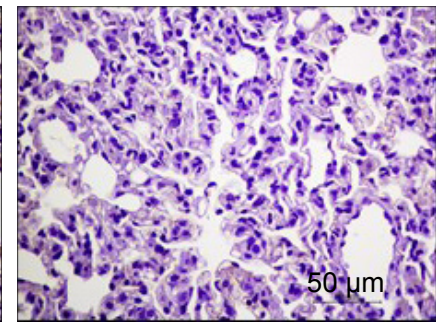

Figure S7 Ferritin $\mathrm{H}$ chain immunohistochemistry.

Notes: Arrows indicate localization of ferritin $\mathrm{H}$ in alveolar cells of the different groups. Original magnification $\times 200$. Scale bar $50 \mu \mathrm{m}$. Cell types and tissue are indicated as alveolar sac (AS). IIM, iron isomaltoside 1000 (Monofer $^{\circledR}$, Pharmacosmos A/S, Holbæk, Denmark); IS, iron sucrose (Venofer ${ }^{\circledR}$, American Regent, Shirley, NY, USA); FCM, ferric carboxymaltose (Ferinject ${ }^{\circledR}$, Vifor (International) Ltd., St Gallen, Switzerland); FMX, ferumoxytol (Feraheme ${ }^{\circledR}$, AMAG Pharmaceuticals Inc., Lexington, MA, USA); LMWID, low molecular weight iron dextran (Infed ${ }^{\circledR}$, Watson Pharma Inc., Morristown, NJ, USA); control, saline treatment.

\section{Publish your work in this journal}

Drug Design, Development and Therapy is an international, peerreviewed open-access journal that spans the spectrum of drug design and development through to clinical applications. Clinical outcomes, patient safety, and programs for the development and effective, safe, and sustained use of medicines are the features of the journal, which has also been accepted for indexing on PubMed Central. The manuscript management system is completely online and includes a very quick and fair peer-review system, which is all easy to use. Visit http://www.dovepress.com/testimonials.php to read real quotes from published authors. 